\title{
CLIL TECHNOLOGY AS AN INNOVATIVE METHOD TO LEARN FOREIGN LANGUAGES AT UNIVERSITY
}

\author{
E.G. Shraiber, shraibereg@susu.ru, \\ L.N. Ovinova, ovinovaln@susu.ru \\ South Ural State University, Chelyabinsk, Russian Federation
}

\begin{abstract}
The article deals with the CLIL technology as an innovative method of foreign languages teaching in higher education. Current social, political and economic background demands introducing integrated approaches to the higher education system in order to train future specialists capable of intellectual flexibility and integrated task solution.

The paper touches upon the history and the methodological peculiarities of the technology, benefits of its implementation in higher education; suggests CLIL activities that might be used at language classes; highlights the difficulties the academic staff may experience and submits possible outcomes and solutions of how to implement the CLIL-technology into the system of higher education through administrative resources of the university.

In this regard, certain specific literature and recent researches review, observation and analysis of the professional activities of the academic staff were used to choose the CLIL technology as one of the possible methods aimed at training the specialists the modern society calls for.

As a result, having analysed the history, methodology and core features of the CLIL technology in general, we come to a conclusion that it may be completely or partially implemented in the system of higher education. Obvious problems of content and language teachers while following this technology were identified as well as possible options of solution were put forward.

Keywords: CLIL, integration, higher education, innovative methods, professional development, co-operation.
\end{abstract}

We live in a time of innovations which are the highlight of any field of science and education nowadays. Modern social and economic tendencies have placed greater demands on higher education, and on linguistic education, in particular. That is why nowadays it is really important to introduce innovative methods and technologies of higher education aimed at training the new generation of future specialists who stick to a flexible and original way of thinking in the modern context. These requirements are fixed in the educational legislative papers of different levels. Thus, the most crucial paper that regulates the legal basis for education in the Russian Federation Federal Law on Education (No. 273-FZ, adopted on 29 December 2012) - states that innovative activity in the sphere of education is carried out to modernize and develop the system of education and is focused on enhancing scientific, methodological, organizational maintenance of education... in the form of innovative projects and programs... [3, Art.20].

Moreover, the Roadmap for the Competitiveness Enhancement Program of South Ural State University for 2016-2020 also claims the necessity for innovations in Education. Within the Federal program " $5-100$ " the University aims at improving the quality and efficiency of education through implementing new educational models and technologies [10]. So, SUSU strives to improve quality of education by training teachers and launching innovative educational methods.

The claim for introducing innovative methods and technologies in higher education touches the questions about an innovative activity of lecturers and professors and their readiness to implement it as a part of their professional development.

In a broader sense innovation is thought to be a kind of any activity or a process which results in new ideas emergence, a new product or technology appearance with its further implementation into the existing system $[5,6]$. Innovative activity of a lecturer or a professor is a search for new methods and technologies, designing of brand new educational strategies, acquisition and adaptation of presently existing educational innovations in the world and their further introduction to the educational system.

In a highly integrated world integrated methods of learning have become more and more incentive. As a result, one of the modern innovations in the sphere of educational technologies - 
CLIL-technology - is becoming more popular all over the world recently. "The mindset of Generation $\mathrm{Y}$ is particularly focused on immediacy as in "learn as you use, use as you learn" [8, p. 11]. The term CLIL (Content and Language Integrated Learning) was coined by David March in 1994. However, it has a much longer history.

The approach to learn a language through the content was suggested by the Czech philosopher, pedagogue John Amos Comenius, who underlined the importance of effective foreign languages teaching. The next pedagogue to be mentioned is Matthias Bel. Bel was active in the fields of pedagogy, philosophy, philology, history. He was a director of two grammar schools located in a multilanguage community where he tried to facilitate the process of foreign languages learning. Learning a language for Bel is an acquisition of school subjects. He insisted on using new vocabulary to learn the reality and the world around.

Up to 1970 programmes of content and language integrated learning were used in the specific linguistic regions to help children pick up the language through bilingual instructions. Canada is one of the first countries where bilingual programmes were applied.

Later programmes of language immersion designed to teach both the content and non-native languages were widely spread throughout Canada, the USA and other countries.

In 1966 another method of learning foreign languages appeared in England: LAC (Language Across the Curriculum) based on cross-curricular approach.

The success of the above-mentioned programmes of integrated learning attracted the attention of Europeans, who were interested in a language policy developing. The 1983 Regulation of the European parliament promoted a new programme to enhance the quality of foreign languages teaching.

As it has already been noted the acronym CLIL was coined by David March - one of the researches in the field of bilingual learning in the University of Jyväskylä, Finland in 1994. In 2005 he put forward CLIL as a general term for different two-way methods which focused on content and language [7]. Recent researches on CLIL, being more concentrated on the linguistic side of the technology, have risen up because of the integrated approach to study the phenomenon by linguists, pedagogues, psychologists, neurologists and etc. Besides, another goal to study two-way (content and language) learning is a research on students' cognitive skills. At present many European universities deliver CLIL teacher training courses.

So, CLIL is a tool to teach and learn content and language together. The most important thing about CLIL is integration. We include language learning in content class and vice versa, content learning in language-learning class. So, one has to focus on content and learning together. But it's not all. There is a third element that is no less important - learning skills which support the acquisition of content and language. Thus, we have a ternary technology which should be implemented into a larger context: content, language and learning skills. These are three main goals of CLIL-style education.

The following suggested activities show the fusion of three goals in content and language integrated learning. Thus, students (future historians) explore the history of medieval England by reading and discussing the questions using the Past Simple Tense, or they (future physicists) carry out an experiment and describe it using comparative and superlative degrees of adjectives [16]. Future lawyers describe the criminal justice procedure using conjunctions and connectives or simulate the interviewing of a witness using Past Simple and Past Continuous questions. Future food technologists describe and invent their own recipes using Passive Voice. Potential sociologists learn to make a survey and present it in the form a chart or diagram using specific terminology. Future engineers get familiar with different machines operation and describe them using Passive Voice, etc. All in all, one can find the CLIL triad here: content, language and learning skills (Fig. 1).

The authors of the book "Uncovering CLIL" single out the core features of CLIL methodology. They are multiple focus, safe and enriching learning environment, authenticity, active learning, scaffolding, and co-operation [8, p. 99].

Under multiple focus we understand the opportunity to learn language in non-language classes, and vice versa, to learn content in language classes. This approach is based on the principle of several subjects integration [14]. Content and language learning allows to work on cross-cultural themes and projects. Safe and enriching learning environment implies using routine class activities and, as a consequence, building student confidence. Besides, it also stands for availability of authentic materials and 


\section{Теория и методика профессионального образования}

students' awareness of language competence developing. Authenticity means students indicating language needs, accommodating student interests, connecting learning and the students' lives, connecting with speakers of the CLIL language and using current materials. Active learning manifests itself through favouring peer cooperative work, negotiating, teachers acting as facilitators, students communicating more than teachers, students help to set learning outcomes. Scaffolding means building on a student's existing knowledge, skills, attitudes, interests and experience, repackaging information in user-friendly ways, responding to different learning styles, fostering creative and critical thinking. Co-operation implies planning lessons in co-operation with CLIL and non-CLIL teachers, involving the local community and authorities. school or vocational education. However, the 2003 conference in Maastricht devoted to CLIL in higher education seemed to be the platform for the importance of CLIL in the higher education level and caused the introduction of a new concept ICLHE (integrating content and language in higher education) which means the integration of content and language in the system of higher education [4, p. 41].

The reasons for CLIL implementation in higher education are explained by U. Smith who says that separate learning of a language becomes useless in higher education. More attention has to be paid to the balanced teaching approach based on the content and language integration [13, p. 38].

Theoretical grounds of bilingual learning on the basis of content and language integration in a non-linguistic university are devised by

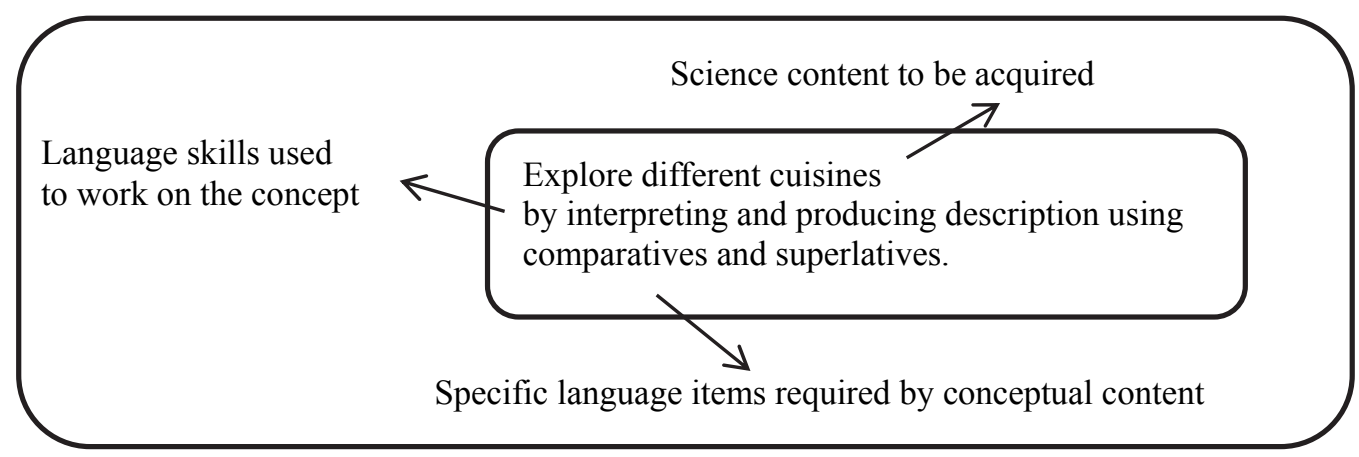

Fig.1. CLIL triad: content, language, learning skills

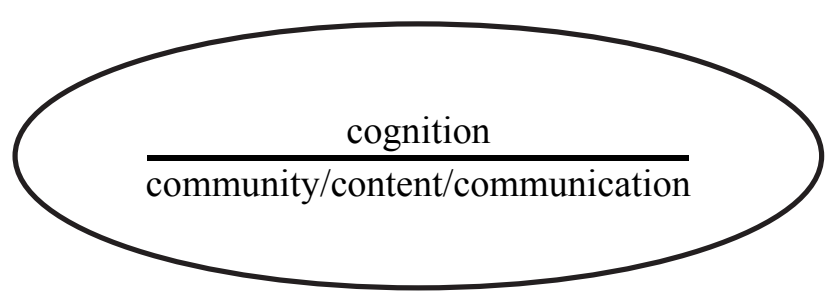

Fig. 2. The CLIL model

All these core features of the CLIL model are driven by the following four principles: cognition, community, content and communication (4-C CLIL model, Fig.2):

Good CLIL practice is driven by cognition (thinking), which is the mental faculty of knowing. In CLIL, the primary focus is on content as opposed to form. Moreover, as meaning-making is both a personal and a social process - (community), new knowledge and skills develop through personal as well as co-operative reflection/analysis (cognition) and through a communicative process (communication) [8, p. 31].

There are a plenty of researches about CLIL implementation into the primary, secondary the following researchers: L.L. Salekhova, F. Ball, D. Coyle, O. Meyer and others [1, 2, 9, 11].

They put forth the following benefits of using CLIL in higher education:

1. Integrated classes increase students' motivation to language learning, as students consider the language as a means to learn another subject and to gain new interesting information. "It is a student's desire to understand and use the content that motivates him or her to learn the language" [8, p. 11].

2. Students have much more opportunities to speak and write about processes they watch and analyse. Then they are able to share their experience with other students in the class. 
3. Students learn to apply new knowledge and skills.

4. Language learning becomes a powerful tool for enlarging professional knowledge and skills [12].

5. It helps to broaden the outlook and cultural values.

6. Students learn to co-operate and be independent.

7. It creates a "real-life" experience and focuses on the innate language learning ability we all had as young children and adolescents.

8. The flexibility of this approach is evident as it could be easily applied to different learning context, curricular or educational systems.

But nevertheless, there are some difficulties experienced by professors which are quite evident: delivering content in a foreign language (maths, physics, psychology, etc.) may bring difficulties to content teachers and it may be troublesome to teach them a foreign language, and vice versa, language teachers meet some problems with explaining the content at their language classes. As it is universally acknowledged educational innovation outpaces teacher education provision. As a programme expands from primary and secondary school into higher education an increasing number of CLIL teachers are required. Teacher training institutions in many countries do not prepare teachers for CLIL. The number of teachers who speak a given CLIL language and have subject-area qualifications is limited. Even if they have such skills, not all teachers are prepared to focus on content and language goals [8, p. 21].

Major attention is to be focused on linguistic training of the staff. The first step is to examine the staff's language skills. Some people might require a language refresher course and it is also helpful to encourage the university to offer a number of English-language online courses in the massive open online course (MOOC) or a group learning format. Some professors who are relatively good at the CLIL language may consider doing a professor exchange: native speaker of the CLIL language may come to the university and our colleagues might go abroad and develop their language skills. It is also important to involve local authorities so that they understand future staffing needs and provide the support. CLIL technology requires considerable teamwork and collaboration because they constitute a professional challenge. This practice is of great interest to those who want to try something new. To satisfy the requirements of the staff SUSU offers some new projects aimed at tea- chers training and support in their desire to develop themselves and their professional qualification. Pilot projects show that such initiative significantly improves teaching quality: teachers first get to know the new technology and best practices in teaching and then get the chance to examine themselves and to work under the innovative schemes.

Another problem connected with the CLIL technology implementation is time-consuming preparation for the classes. It takes a conscious effort to set content, language and learning skills goals for every class [8]. Moreover, if you are a language teacher and you try to apply some bits of the technology during your language classes within the English for Specific Purposes (ESP) course designed for $4^{\text {th }}$ term bachelors, you will have to spend considerable time developing or adapting existing learning resources. Being a language teacher your efforts to do it are multiplied by preparing for different content classes as groups you have to work with are from different faculties of the university. To find appropriate materials for a particular group is another challenge for teachers. The language should be simple enough, materials - presented in a learningfriendly manner, with content being sufficiently rich and cognitively challenging to capture students' interest. As a way out one can offer is to establish reciprocal relationships and to share the experience. Luckily, there are some useful internet resources that might be helpful both for teachers and students on the sites: One Stop English, British Council или CLIL Media, Macmillan's Inspiration, etc. [15, 16].

So, to relieve the stress, teachers may have, it should be born in mind that the CLIL technology requires more preparation time and greater co-operation among teachers. It could be supported by university administration creating special CLIL-programmes based on cross-curricular projects. Cross-curricular projects may be based on themes such as environment or ecology, developing a particular economic policy of the region or innovative engineering technologies, globalization or any common human problems, etc. Above all, it is vitally important for the university administration and local authorities to support and manage co-operation.

\section{References}

1. Ball Ph. What is CLIL? Available at: http://www.onestopenglish.com/clil/methodology/ articles/article-what-is-clil/500453.article (accessed 15.03.2017). 


\section{Теория и методика профессионального образования}

2. Coyle D., Hood Ph., March D. CLIL: Content and Language Integrated Learning. Cambridge, Cambridge University Press, 2010. $170 \mathrm{p}$.

3. Federal'nyy zakon "Ob obrazovanii v Rossiyskoy Federatsii" ot 29.12.2012 № 273 [Federal Law "On Education" of 29.12.2012 No. 273]. Available at: http://www.consultant.ru/ document/cons_doc_LAW_140174/ (accessed 15.03.2017).

4. Fortanet-Gomez I. CLIL in Higher Education towards a Multilingual Language Policy. Bristol, Multilingual Matters Publ., 2013. $312 \mathrm{p}$.

5. Kotlyarova I.O. [Continuous Training of Technical Specialities Students for Innovation Activity]. Bulletin of the South Ural State University. Ser. Education. Pedagogy, 2012, vol. 17, no. 26, pp. 15-19. (in Russ.)

6. Kotlyarova I.O. [The Development of the Social Sphere Manager Readiness to the Innovations in Energy Saving as an International Challenge]. Bulletin of the South Ural State University. Ser. Education. Pedagogy, 2013, vol. 5, no. 4, pp. 39-46. (in Russ.)

7. Marsh D. Content and Language Integrated Learning (CLIL). A Development Trajectory. Available at: http://www.includenetwork. eu/DOCUMENTS/36_CLIL_A_DEVELOPMEN T.pdf (accessed 15.03.2017).

8. Mehisto P., Marsh D., Frigols M.J. Uncovering CLIL. Content and Language Integrated Learning in Bilingual and Multilingual Education. Oxford, Macmillan Education Publ., 2012. $238 \mathrm{p}$.

9. Meyer O. Introducing the CLILPyramid: Key Strategies and Principles for Quality CLIL Planning and Teaching. Basic Issues in EFL-Teaching and Learning, 2010, pp. 11-29.
10. Roadmap for the Competitiveness Enhancement Program of South Ural State University for 2016-2020. Available at: https://www. susu.ru/sites/default/files/book/susu_rm_english_ final_1.pdf (accessed 15.03.2017).

11. Salekhova L.L., Grigorieva K.S. [Content and Language Integrated Learning as a Basis for Students' Professional Foreign Language Competence Forming at the Technical University]. Inostrannyy yazyk dlya professional'nykh tseley: traditsii i innovatsii: sbornik statey vtorogo zaochnogo respublikanskogo simpoziuma [Foreign Languages for Professional Purposes: Traditions and Innovations: Collected Articles of the II Correspondence Republican Symposium]. Kazan', 2013, pp. 89-94. (in Russ.)

12. Serikov G.N. [Socially Significant Aspects of Self-Identity]. Bulletin of the South Ural State University. Ser. Education. Pedagogy, 2014, vol. 6, no. 4, pp. 27-32. (in Russ.)

13. Smith U. English as a Lingua Franca in Higher Education. A Longitudinal Study of Classroom Discourse. Berlin, De Gruyter Publ., 2010. 150 p. DOI: $10.1515 / 9783110215519$

14. Usova A.V. [Methodological Bases of University Students' Vocational Training]. Bulletin of the South Ural State University Ser. Education. Pedagogy, 2012, vol. 15, no. 4, pp. 9-11. (in Russ.)

15. Vaindorf-Sysoeva M.E. [Virtual Educational Environment as an Integral Component of Modern Educational System]. Bulletin of the South Ural State University Ser. Education. Pedagogy, 2012, vol. 16, no. 14, pp. 86-91. (in Russ.)

16. What is CLIL or Learn the World Through English. Available at: http://proenglishblog.ru/metody-i-metodiki/chto-takoe-clil-ilipoznaem-mir-cherez-anglijskij.html (accessed 15.03.2017).

Received 17 March 2017 


\title{
ТЕХНОЛОГИЯ CLIL КАК ИННОВАЦИОННЫЙ МЕТОД ОБУЧЕНИЯ ИНОСТРАННЫМ ЯЗЫКАМ В ВУЗЕ
}

\author{
Е.Г. Шрайбер, Л.Н. Овинова \\ Южно-Уральский государственный университет, г. Челябинск
}

\begin{abstract}
В статье описывается технология CLIL как инновационный метод обучения иностранным языкам в высшем образовании. Современная социально-политическая и экономическая ситуация требует внедрения интегрированных подходов обучения в высшем образовании с целью подготовки будущих специалистов, обладающих гибким мышлением и умением подходить к решению задач комплексно.

В статье рассматриваются история и методические особенности данной технологии, ее преимущества в системе высшего образования; представлены примерные задания на основе описываемой технологии; обозначены трудности, с которыми сталкиваются преподаватели в ходе реализации данной технологии; предложены возможные варианты ее внедрения и преодоления возникающих трудностей с помощью административного ресурса университета.

Методы исследования, использованные авторами данной статьи, включают в себя анализ специальной литературы, правовых и других документов в области высшего образования, наблюдение и анализ профессиональной деятельности преподавательского состава университета.

В результате анализа истории и методики применения данной технологии, авторы приходят к заключению о целесообразности внедрения данной технологии в систему высшего образования, предлагая варианты решения данной задачи.

Ключевые слова: предметно-языковое интегрированное обучение, интеграция, высшее образование, инновационные методы, профессиональное развитие, сотрудничество.
\end{abstract}

\section{Лumepamypa}

1. Ball, Ph. What is CLIL? / Ph. Ball. - http://www.onestopenglish.com/clil/methodology/articles/ article-what-is-clil/500453.article (дата обращения 15.03.2017).

2. Coyle, D. CLIL: Content and Language Integrated Learning / D. Coyle, Ph. Hood, D. March. Cambridge: Cambridge University Press, 2010. - 170 p.

3. Федеральный закон «Об образовании» № 273-Ф3 от 29.12.2012. - http://www.consultant.ru/ document/cons_doc_LAW_140174/(дата обращения 15.03.2017).

4. Fortanet-Gomez, I. CLIL in higher education towards a multilingual language policy / I. Fortanet-Gomez. - Bristol: Multilingual Matters, 2013. - 312 p.

5. Котлярова, И.О. Непрерывная подготовка студентов технических направлений к инновационной деятельности / И.О. Котлярова // Вестник ЮУрГУ. Серия «Образование. Педагогические науки». - 2012. - T. 17, № 26. - С. 15-19.

6. Котлярова, И.О. Развитие готовности менеджера сочиальной сферы к инновациям в области энергосбережения как межнациональная задача / И.О. Котлярова // Вестник ЮУрГУ. Серия «Образование. Педагогические науки». - 2013. - T.5, № 4. - C. 39-46.

7. Marsh, D. Content and Language Integrated Learning (CLIL). A Development Trajectory / D. Marsh. - http://www.includenetwork.eu/DOCUMENTS/36_CLIL_A_DEVELOPMENT.pdf (dama обращения 15.03.2017).

8. Mehisto, P. Uncovering CLIL. Content and Language Integrated Learning in Bilingual and Multilingual Education / P. Mehisto, D. Marsh, M.J. Frigols. - Oxford: Macmillan Education, 2012. $238 p$.

9. Meyer, O. Introducing the CLIL-Pyramid: Key Strategies and Principles for Quality CLIL Planning and Teaching / O. Meyer // Basic issues in EFL-Teaching and Learning. - 2010. - P. 11-29. 


\section{Теория и методика профессионального образования}

10. План мероприятий по реализачии программы повышения конкурентоспособности ЮУрГУ («дорожная карта»). - https://www.susu.ru/sites/default/files/book/susu_rm_english_final_1.pdf (dama обращения 15.03.2017).

11. Салехова, Л.Л. Content and Language Integrated Learning как основа формирования профессиональной иноязычной компетениии студентов технических вузов / Л.Л. Салехова, К.С. Григорьева // Иностранный язык для профессиональных иелей: традиции и инновачии: Сб. ст. II заоч. республик. симп. - Казань: К(П)ФУ, 2013. - С. 89-94.

12. Сериков, Г.Н. Сочиально-значимые аспекты самоопределения личности / Г.Н. Сериков // Вестник ЮУрГУ. Серия «Образование. Педагогические науки». - 2014. - T.6, № 4. - С. 27-32.

13. Smith, U. English as a Lingua Franca in Higher Education. A Longitudinal Study of Classroom Discourse / U. Smith. - Berlin: De Gruyter, 2010. - 150 p.

14. Усова, А.В. Методологические основы профессиональной подготовки студентов вузов / А.В. Усова // Вестник ЮУрГУ. Серия «Образование. Педагогические науки». - 2012. - T. 15, № 4. C. $9-11$.

15. Вайндорф-Сысоева, М.Е. Виртуальная образовательная среда как неотъемлемый компонент современной системы образования / М.Е. Вайндорф-Сысоева // Вестник ЮУрГУ. Серия «Образование. Педагогические науки». - 2012. - Т. 16, № 14. - С. 86-91.

16. What is CLIL or Learn the World Through English. - http://proenglish-blog.ru/metody-i-metodiki/ chto-takoe-clil-ili-poznaem-mir-cherez-anglijskij.html (дата обращения 15/03/2017).

Шрайбер Елена Григорьевна, доцент кафедры иностранных языков, Южно-Уральский государственный университет, shraibereg@susu.ru.

Овинова Лада Николаевна, доцент кафедры иностранных языков, Южно-Уральский государственный университет, ovinovaln@susu.ru.

Поступила в редакцию 17 марта 2017 2.

\section{ОБРАЗЕЦ ЦИТИРОВАНИЯ}

Shraiber, E.G. CLIL Technology as an Innovative Method to Learn Foreign Languages at University / E.G. Shraiber, L.N. Ovinova // Вестник ЮУрГУ. Серия «Образование. Педагогические науки». - 2017. - Т. 9, № 2. - С. 82-88. DOI: $10.14529 /$ ped170208

\section{FOR CITATION}

Shraiber E.G., Ovinova L.N. CLIL Technology as an Innovative Method to Learn Foreign Languages at University. Bulletin of the South Ural State University. Ser. Education. Educational Sciences. 2017, vol. 9, no. 2, pp. 82-88. DOI: 10.14529/ped170208 